\title{
The Healing Analysis of II Degree Burn from Surgery Essential Oil Ointment (Curcuma Longa) in Wistar Rats (Rattus Norvegicus)
}

\author{
Chen Wei ${ }^{1}$, Florenly ${ }^{2}$, Dewi Riastawaty Purba ${ }^{3}$, Fioni ${ }^{4}$ \\ ${ }^{1,2,3,4}$ Departement of Medicine, Faculty of Medicine, Universitas Prima Indonesia \\ fioni@unprimdn.ac.id
}

\begin{abstract}
Data in Indonesia the death rate from burns is still high at around 40\%, mainly caused by severe burns. The most potential medicinal turmeric plant is its rhizome, which contains the phenolic compound curcumin and essential oils. Some of the benefits of turmeric antioxidants, anti-inflammatory, anti-cancer, acetylcholinesterase activity inhibitors, anti-fungal, and anti-bacterial. This study aims to find out the phytochemical content and effects of Turmeric Essential Oil Ointment (Curcuma longa Linn) in curing grade II burns in Wistar rats (Rattus norvegicus). This type of research is experimental with a pre-post approach and post-test control group design. The study was conducted at Riwandi Pet Shop and Animal House March-May 2021. The research sample is turmeric (Curcuma longa) obtained from a traditional market in the city of Medan and identified in herbarium Medanese (MEDA), Laboratoirum Taxonomy of Plants, Department of Biology, Faculty of Mathematics and Natural Sciences (FMIPA), University of North Sumatra, Medan. The test animal is a Wistar strain rat with as many as 20 tails divided into 4 treatment groups, so each group consists of 5 rats. The results of the study contained significant differences in the epithelial period of the standard group, $10 \%$ turmeric ointment and $15 \%$ against the control group. However, in the turmeric ointment group and the standard group, there was no difference in epithelialization periods. This is evident from the value $P<0.05$ (Value $P=0.029$ ). The healing effects of burns possessed by Turmeric ointment are both $10 \%$ and $15 \%$ and nebacetin ointment as standard shows significant differences. Where the wound contraction rate of turmeric ointment is $15 \%$ better than nebacetin ointment as standard. But in both turmeric ointments, both $10 \%$ and $15 \%$ and nebacetin ointment as standard did not show significant differences in the parameters of the epithelial period.
\end{abstract}

Keywords: wounds; burns; essentials; turmeric

\section{Introduction}

The World Health Organization (WHO) notes that burns cause about 195,000 deaths in Indonesia each year. The prevalence of injuries increases every year, burns rank sixth cause of unintentional injury (unintentional injury) after a fall, motorcycle, and others (Badan Penelitian Dan Pengembangan Kesehatan Kementerian Kesehatan RI 2013). In 2008, more than 410,000 burns occurred in the United States, with about 40000 requiring hospital treatment. In India, more than 1 million people suffer burns each year (Fitria, Saputra, and Revilla 2014). Until now, burns are still a chor for clinical nurses as severe burns have led to high postburn morbidity. Data in Indonesia the death rate from burns is still high at around 40\%, mainly caused by severe burns (Mutia 2015).

Combustion is an injury as a result of direct contact or exposure to sources of heat (thermal), electricity, chemicals, or radiation (Tutik Rahayuningsih 2012). Based on depth, burns are divided into 4 types: superficial (degree 1), deep partial-thickness (degree 2), full-thickness (level 3), and level 4 (Hakim 2020). Burns can usually be prevented, and 
different treatments are applied based on the severity of the burn. Sometimes, ointments, creams, biological and nonbiological dressings, and antibiotics are recommended levels 2 , 3 , and 4 burns, while misuse of such drugs can increase the risk of antibiotic resistance and fungal infections, even slowing wound healing and increasing the depth of burns (Avni et al. 2010).

The most potential turmeric plant as a remedy is its rhizome. The turmeric rhizome contains phenolic compounds, one of which is curcumin (Nabofa et al. 2018). In addition to curcumin compounds, in the rhizome turmeric also contains essential oil (Safwan, Yuliani, and Pramono 2014). Some of the benefits of turmeric from the results of the research are turmeric is antioxidant (Wanninger et al. 2015); (Razavi 2021), antiinflammatory (Manarin et al. 2019); (Setiadi, Khumaida, and Wahyuning Ardie 2017); (Kocaadam and Şanlier 2017), Anti-cancer (Hartati 2013); inhibitor of acetylcholinesterase activity (Safwan et al. 2014), Anti-fungal and anti-bacterial (Nadifah, Farida Muhajir, and Retnoningsih 2018), larvisidal mosquito Ae. Aegypti (Panghiyangani 2010). Based on background, researchers are interested in conducting research aimed at finding out the phytochemical content and the effects of Turmeric Essential Oil Ointment (Curcuma longa Linn) in curing grade II burns in Wistar rats (Rattus norvegicus).

\section{Review of Literature}

Turmeric with the scientific name Curcuma longa Linn is one of the spice plants and is also a medicinal plant (Ariani 2017); (Sabale, Modi, and Sabale 2013). The main compound of turmeric is curcumin (Nabofa et al. 2018). Turmeric rhizome contains 1.5$2.5 \%$ essential oil, curcumin, resin, oleoresin, curcumin deoxy, and curcumin bisdesmetoction. Tumeron, karvakrol, $\alpha$-felandren, and terpinolen are the constituents that make up the most essential oils in several varieties of turmeric (L.A. Usman 2009). Among these active ingredients, which act as antimicrobials, such as to inhibit the perplant fungus Candida albicans, are curcumin, flavonoids, and essential oils. Curcumin and essential oils can be obtained through the cold extraction process (maceration) with $96 \%$ ethanol. In addition to using extraction, essential oils in turmeric rhizomes can also be obtained through distillation (Zorofchian Moghadamtousi et al. 2014). The National Cancer Institute has clarified that turmeric plants are non-toxic, even at high doses, so they are recognized as safe ingredients (GRAS=Generally recognized as safe) (Itokawa et al. 2008). The skin is part of the integumental system there are three main layers of skin: epidermis, dermis, and hypodermis (subcutaneous fat). The focus of this topic is on the skin layer of the epidermis and skin. Skin appendages such as sweat glands, hair follicles, and sebaceous glands are in-depth reviewed elsewhere (Kalangi 2014).

\section{Research Methods}

This type of research is experimental with a pre-post approach and post-test control group design. The study was conducted at Riwandi Pet Shop and Animal House from March to May 2021. Research samples of turmeric plants (Curcuma longa) were obtained from traditional markets in the city of Medan and identified in the Herbarium Medanese (MEDA), Laboratoirum Taxonomy of Plants, Department of Biology, Faculty of Mathematics and Natural Sciences (FMIPA), University of North Sumatra, Medan. Animal samples tried in this study are Wistar strain rats as many as 20 male Wistar rats 
(Rattus norvegicus) divided into 4 treatment groups so that each group consists of 5 rats (Setyopuspito Pramitaningastuti 2017).

\subsection{Tool}

Maceration vessels, knives, rotary evaporators, water handlers, gel containers, stirrer rods, plates measuring $2 \times 2 \mathrm{~cm}$.

\subsection{Material}

Turmeric, aquades, lanolin, solid paraffin, Cetostearyl alcochol, white vaseline, gauze, oil paper, filter paper, 1mm2-sized paper, oil paper, nebacetin ointment ${ }^{\circledR}$.

\subsection{Research Procedure}

As much fresh turmeric (200 grams) is methylated by Hydro-distillation process for 4 hours at $80 \mathrm{oC}$, the remaining water residue in the distillation results is removed by inserting anhydrous sodium sulfate, which is then filtered to obtain the oil (Negi, Bisht, and Kandari Negi 2012).

As for the calculation of turmeric oil yield (Curcuma longa).

$$
\text { Yield }(\%)=\frac{\text { Curcuma longa Turmeric Essential Oil }) \times 100 \%}{\text { Sample Time Kuyit Curcuma longa) }}
$$

\subsection{Manufacture of Ointment Preparations from Turmeric Essential Oil (Curcuma longa)}

The various materials used are heated according to the melting point of each material. Formulations are made with varying concentrations as shown in the following table:

Table 1. Topical Preparation Formulations of Each Ointment

\begin{tabular}{llll}
\hline \multicolumn{1}{c}{ Material Name } & $\begin{array}{l}\text { Ointment } \\
\text { base }\end{array}$ & $\begin{array}{l}\text { Turmeric } \\
\text { Essential Oil }\end{array}$ & $\begin{array}{l}\text { Turmeric } \\
\text { Essential Oil }\end{array}$ \\
\hline Turmeric Essential Oil (Curcuma & - & $1 \mathrm{ml}$ & $1.5 \mathrm{ml}$ \\
\hline Lanolin & $2.5 \mathrm{~g}$ & $2.5 \mathrm{~g}$ & $2.5 \mathrm{~g}$ \\
\hline Solid paraffin & $2.5 \mathrm{~g}$ & $2.5 \mathrm{~g}$ & $2.5 \mathrm{~g}$ \\
\hline Cetostearyl alcochol & $2.5 \mathrm{~g}$ & $2.5 \mathrm{~g}$ & $2.5 \mathrm{~g}$ \\
\hline White vaseline & $42.5 \mathrm{~g}$ & $42.5 \mathrm{~g}$ & $42.5 \mathrm{~g}$ \\
\hline
\end{tabular}

\subsection{Testing on Animal Trials}

All animals try to do the need to use a modified electric solder with a round-shaped tip and then touched on the dorsal part of the rat for 10 seconds, before doing the needs of the rats dianastesi using ketamine $(50 \mathrm{mg} / \mathrm{kg}$ i.m) that has previously been satisfied. Before continuing with the sampling of extract gels and controls, different tests are carried out to assess the degree and extent of the grade II burn (Thakur et al. 2011);(Verma et al. 2012).

As for the treatment given to 24 wistar rats as tried animals that are divided into groups as in the table below:

Table 2. Perpetrators in the Trial Group

\begin{tabular}{ll}
\hline Group & Treatment \\
\hline Control & In this group only given the base of ointment \\
\hline
\end{tabular}




\begin{tabular}{lrll}
\hline Standard & & & $\begin{array}{l}\text { In this group is used Nebacetin Ointment which is } \\
\text { generally used in the treatment of burns. }\end{array}$ \\
\hline $\begin{array}{l}\text { Turmeric Essential } \\
\text { (Curcuma Longa) } 10 \%\end{array}$ & Oil & Saleb & $\begin{array}{l}\text { In this group is given turmeric essential oil } \\
\text { ointment (Curcuma longa) } 10 \%\end{array}$ \\
\hline $\begin{array}{l}\text { Turmeric Essential } \\
\text { (Curcuma Longa) } 15 \%\end{array}$ & Oil & Saleb & $\begin{array}{l}\text { In this group is given turmeric essential oil } \\
\text { ointment (Curcuma longa) } 15 \%\end{array}$ \\
\hline
\end{tabular}

Each treatment of each group of mice was carried out on the day that the need was carried out on the mice until the release of the eschar. Burns evaluation is carried out every 2-4 days, with aspects evaluated from the healing activities of the burn including wound contration and epithelialization periods (Thakur et al., 2011). Wound contration is measured by displacing the diameter of the wound using a ruler, then wound contraction is calculated by the following formula (Verma et al. 2012); (Thakur et al. 2011):

Wound Contraction $(\%)=($ Initial wound size - the size of the wound on a specific day $) x$ $100 \%$

Size of the wound on a specific day

The epithelialization period is measured by calculating the length of time eschar is removed to escape, during which the epithelial period is calculated in the day (Thakur et al. 2011); (Verma et al. 2012). The statistical analysis used in the study was a one-way Anova test, followed by a post-hoc test. Before another test is done descriptive analysis of wound contraction and epithelial period. If the data in this study is distributed abnormally, then there will be a transformation of the data so that the data is distributed normally.

\section{Discussion}

\subsection{Characteristics of Essential Oils}

Characteristics of essential oils evaluated in the study include the initial weight of the rimbang, the weight of the resulting essential oil, the volume of essential oils, and the yield.

Table 3. Characteristics of Turmeric Essential Oil (Curcuma longa Linn)

\begin{tabular}{ll}
\hline Parameters & Massive \\
\hline Early Weight of Rimbang (gr) & $1000 \mathrm{gr}$ \\
\hline Weight of Essential Oil $(\mathrm{gr})$ & $2.54 \mathrm{gr}$ \\
\hline Volume of Essential Oil $(\mathrm{ml})$ & $2.5 \mathrm{ml}$ \\
\hline Yield $(\% \mathrm{v} / \mathrm{b})$ & $0.25 \%$ \\
\hline
\end{tabular}

From the table data above can be seen from 1,000grams of turmeric period (Curcuma longa Linn) used after distillation was found as much as $2.5 \mathrm{ml}$ of turmeric essential oil (Curcuma longa Linn). Until it found a yield value of $0.25 \%$.

\subsection{Turmeric Phytochemical Screening (Curcuma longa Linn)}

Turmeric used in this study conducted a phytochemical screening test to find out the phytochemical content of turmeric samples (Curcuma longa). The results of the screening can be seen in the table below. 
Table 4. Turmeric Phytochemical Screening Results (Curcuma longa Linn)

\begin{tabular}{llc}
\hline Phytochemicals & Test Method & Result \\
\hline Alkaloid & Dragendorff & + \\
\hline Steroid & Maeyer & + \\
& Salkowsky & - \\
\hline Saponin & Aquadest & - \\
& Aquadest + Alkohol 96\% & - \\
\hline Flavonoid & $\mathrm{FeCl} 35 \%$ & + \\
& $\mathrm{NaOH} \mathrm{10 \%}$ & + \\
\hline Tannins & $\mathrm{FeCl3}$ & + \\
\hline
\end{tabular}

From the results of phytochemical screening in fresh samples of turmeric (Curcuma longa Linn) found phytochemical content in the form of alkaloids, flavonoids, and tannins. The results of the study in line with those conducted by Maulidya and Sari (2016) in Cobra (2019), stated that the content of turmeric rhizomes consists of alkaloid compounds, flavonoids, and tannins (Cobra 2019). Different from the results of the study (Lia Fikayuniar, Neni Sri Gunarti, and Mellya Apriliani 2019), where the results of his research with phytochemical tests, in the simplisia rhizome turmeric showed positive results in alkaloids, flavonoids and terpenoids. While in ethanol extract turmeric rhizomes showed positive results in alkaloids, flavonoids, phenols, terpenoids, and tannins. Undetectable phenol and tannin compounds in simplisia can be caused by the polar differences of the solvents used with those compounds. According to (Sirwutubun et al. 2016), solvents can extract compounds that have the same polarity or similar to the polarity of the solvent used.

\subsection{Wound Healing Activities}

From table 5 data it can be seen that the wound contraction parameter data on day 6 and day 9 shows a normal data distribution, so the analysis of data used for other tests is One Way Anova followed by Post Hoc Test Tukey HSD. Meanwhile, other parameters show an abnormal distribution of data so that different tests used are kruscal-wallis and mann-whitney tests.

Table 5. Results of Data Normality Analysis on Burn Healing Parameters

\begin{tabular}{ll}
\hline Wound Healing Parameters & P-Value \\
\hline Wound Contraction on Day 3 & 0.021 \\
\hline Wound Contraction on Day 6 & 0.322 \\
\hline Wound Contraction on Day 9 & 0.056 \\
\hline Wound Contraction on Day 12 & 0.035 \\
\hline Wound Contraction on Day 14 & 0.003 \\
\hline Epithelial period & 0.002 \\
\hline
\end{tabular}




\subsection{Wound Contraction}

As one of the parameters of wound healing the test results differ from wound conctraction in each treatment group shown in the following table.

Table 6. Results of analysis of One Way Anova and Kruskal-Wallis with Wound Contraction as Wound Healing Parameters in The Treatment Group

\begin{tabular}{lllcll}
\hline $\begin{array}{c}\text { Observation } \\
\text { Time }\end{array}$ & Control & Standard & $\begin{array}{c}\text { Turmeric } \\
\text { Essential Oil } \\
\text { Ointment } \\
(\mathbf{1 0 \%})\end{array}$ & $\begin{array}{c}\text { Turmeric } \\
\text { Essential Oil } \\
\text { Ointment } \\
(\mathbf{1 5 \%})\end{array}$ & P-Value \\
\hline Day -3 & $3.73(8.13)$ & $0.06(8.70)$ & $13.64(25.91)$ & $10.71(15.91)$ & $0.007 * *$ \\
\hline Day -6 & $9.36 \pm 5.21$ & $18.72 \pm 10.54$ & $30.08 \pm 7.88$ & $35.67 \pm 7.58$ & $0.000^{*}$ \\
\hline Day -9 & $7.59 \pm 7.92$ & $35.91 \pm 8.05$ & $46.95 \pm 6.55$ & $51.42 \pm 8.92$ & $0.001 *$ \\
\hline Day -12 & $9.52(29.17)$ & $55.56(20.71)$ & $63.64(21.75)$ & $66.67(8.96)$ & $0.023^{* *}$ \\
\hline Day -14 & $28.57(37.50)$ & $82.61(42.46)$ & $77.27(13.64)$ & $89.29(3.64)$ & $0.014 * *$ \\
\hline
\end{tabular}

$*$ The data presented in Mean \pm SD and Value P are found from the results of One Way Anova analysis. **Data presented in Median (Range) and Value $\mathrm{P}$ is found from kruskal-wallis analysis.

From the table data above it can be seen that the $\mathrm{P}$ value of each test at each observation time $<0.05$, this shows that there is a significant wound contraction difference between each group at each unit of observation time. However, in the analysis of the different tests are not clearly explained between which groups there are significant differences. Therefore, the analysis continued with the Tukey HSD and Mann-Whitney Post Hoc Test to compare two groups at each unit of observation time so that it is known between which groups the difference in wound contraction is significant. The results of the analysis can be seen in the following table:

Table 7. Tukey HSD and Mann-Whitney's Post Hoc Test Analysis of Wound Contraction from Each Treatment Group

\begin{tabular}{llll}
\hline $\begin{array}{l}\text { Observation } \\
\text { Time }\end{array}$ & Treatment Group & P-Value \\
\hline Day-3* & Control & Standard & 0.522 \\
& Standard & Turmeric Essential Oil & $0.008^{* * *}$ \\
& Turmeric & Ointment 10\% & $0.008^{* * *}$ \\
& Essential Oil & Turmeric Essential Oil & 0.522 \\
& Ointment & Ointment 15\% & $0.008^{* * *}$ \\
& 10\% & Control & $0.008^{* * *}$ \\
& Turmeric & Turmeric Essential Oil & $0.008^{* * *}$ \\
& Essential Oil & Ointment 10\% & $0.008^{* * *}$ \\
& Ointment & Turmeric Essential Oil & 0.691 \\
& 15\% & Ointment 15\% & $0.008^{* * *}$ \\
& & Control & $0.008 * * *$ \\
& & Standard & 0.691 \\
& & Turmeric Essential Oil & \\
& & Ointment 10\% & \\
\hline Day $-6 * *$ & Turmeric Essential Oil & \\
\hline & Control & Ointment 15\% & 0.290 \\
& Standard & Standard & $0.004 * * *$ \\
\hline
\end{tabular}




\begin{tabular}{|c|c|c|c|c|}
\hline $\begin{array}{l}\text { Observation } \\
\text { Time }\end{array}$ & \multicolumn{3}{|c|}{ Treatment Group } & \multirow{2}{*}{$\frac{\text { P-Value }}{0.000 * * *}$} \\
\hline & Turmeric & \multicolumn{2}{|l|}{ Ointment $10 \%$} & \\
\hline & Essential Oil & \multicolumn{2}{|l|}{ Turmeric Essential Oil } & 0.290 \\
\hline & Ointment & \multicolumn{2}{|l|}{ Ointment $15 \%$} & 0.155 \\
\hline & $10 \%$ & \multicolumn{2}{|l|}{ Control } & $0.020 * * *$ \\
\hline & Turmeric & \multicolumn{2}{|l|}{ Turmeric Essential Oil } & $0.004 * * *$ \\
\hline & Essential Oil & \multicolumn{2}{|l|}{ Ointment $10 \%$} & 0.155 \\
\hline & Ointment & \multicolumn{2}{|l|}{ Turmeric Essential Oil } & 0.697 \\
\hline & $15 \%$ & \multicolumn{2}{|l|}{ Ointment $15 \%$} & 0.000 \\
\hline & & \multicolumn{2}{|l|}{ Control } & $0.020 * * *$ \\
\hline & & & 0.697 \\
\hline & & \multicolumn{2}{|l|}{$\begin{array}{l}\text { Turmeric Essential Oil } \\
\text { Ointment } 10 \%\end{array}$} & \\
\hline & & $\begin{array}{l}\text { Turmeric Essential } \\
\text { Ointment } 15 \%\end{array}$ & Oil & \\
\hline \multirow[t]{14}{*}{ Hari Ke-9** } & Control & \multicolumn{2}{|l|}{ Standard } & $0.000 * * *$ \\
\hline & Standard & \multicolumn{2}{|l|}{ Turmeric Essential Oil } & $0.000 * * *$ \\
\hline & Turmeric & \multicolumn{2}{|l|}{ Ointment $10 \%$} & $0.000 * * *$ \\
\hline & Essential Oil & \multicolumn{2}{|l|}{ Turmeric Essential Oil } & $0.000 * * *$ \\
\hline & Ointment & \multicolumn{2}{|l|}{ Ointment $15 \%$} & 0.161 \\
\hline & $10 \%$ & \multicolumn{2}{|l|}{ Control } & $0.031 * * *$ \\
\hline & Turmeric & \multicolumn{2}{|l|}{ Turmeric Essential Oil } & $0.000 * * *$ \\
\hline & Essential Oil & \multicolumn{2}{|l|}{ Ointment $10 \%$} & 0.161 \\
\hline & Ointment & \multicolumn{2}{|l|}{ Turmeric Essential Oil } & 0.808 \\
\hline & $15 \%$ & \multicolumn{2}{|l|}{ Ointment $15 \%$} & $0.000 * * *$ \\
\hline & & \multicolumn{2}{|l|}{ Control } & $0.031 * * *$ \\
\hline & & Standard & & 0.808 \\
\hline & & $\begin{array}{l}\text { Turmeric Essential Oil } \\
\text { Ointment } 10 \%\end{array}$ & & \\
\hline & & $\begin{array}{l}\text { Turmeric } \quad \text { Essential } \\
\text { Ointment } 15 \%\end{array}$ & Oil & \\
\hline Hari Ke-12* & Control & Standard & & $0.008 * * *$ \\
\hline & Standard & Turmeric Essential Oil & & $0.008 * * *$ \\
\hline & Turmeric & Ointment $10 \%$ & & $0.008 * * *$ \\
\hline & Essential Oil & Turmeric Essential Oil & & $0.008 * * *$ \\
\hline & Ointment & Ointment $15 \%$ & & 0.220 \\
\hline & $10 \%$ & Control & & 0.056 \\
\hline & Turmeric & Turmeric Essential Oil & & $0.008 * * *$ \\
\hline & Essential Oil & Ointment $10 \%$ & & 0.220 \\
\hline & Ointment & Turmeric Essential Oil & & 0.311 \\
\hline & $15 \%$ & Ointment $15 \%$ & & $0.008 * * *$ \\
\hline & & Control & & 0.056 \\
\hline & & Standard & & 0.311 \\
\hline & & $\begin{array}{l}\text { Turmeric Essential Oil } \\
\text { Ointment } 10 \%\end{array}$ & & \\
\hline & & $\begin{array}{l}\text { Turmeric Essential } \\
\text { Ointment } 15 \%\end{array}$ & Oil & \\
\hline Hari Ke-14* & Control & Standard & & $0.008 * * *$ \\
\hline
\end{tabular}




\begin{tabular}{|c|c|c|c|}
\hline \multirow[t]{2}{*}{$\begin{array}{l}\text { Observation } \\
\text { Time } \\
\end{array}$} & \multicolumn{2}{|c|}{ Treatment Group } & \multirow{2}{*}{$\frac{\text { P-Value }}{0.008 * * *}$} \\
\hline & Standard & Turmeric Essential Oil & \\
\hline & Turmeric & Ointment $10 \%$ & $0.008 * * *$ \\
\hline & Essential Oil & Turmeric Essential Oil & $0.008 * * *$ \\
\hline & Ointment & Ointment $15 \%$ & 0.221 \\
\hline & $10 \%$ & Control & $0.032 * * *$ \\
\hline & Turmeric & Turmeric Essential Oil & 0.221 \\
\hline & Essential Oil & Ointment $10 \%$ & $0.008 * * *$ \\
\hline & Ointment & Turmeric Essential Oil & $0.008 * * *$ \\
\hline & $15 \%$ & Ointment $15 \%$ & $0.008 * * *$ \\
\hline & & Control & $0.032 * * *$ \\
\hline & & Standard & $0.008 * * *$ \\
\hline & & $\begin{array}{l}\text { Turmeric Essential Oil } \\
\text { Ointment } 10 \%\end{array}$ & \\
\hline & & $\begin{array}{l}\text { Turmeric Essential } \\
\text { Ointment } 15 \%\end{array}$ & \\
\hline
\end{tabular}

* The $\mathrm{P}$ value is derived from the results of Mann-Whitney analysis between each group. **The $\mathrm{P}$ value is found from the results of the Tukey HSD Post Hoc Test analysis between each group. There is a significant difference between groups compared to the signification of the value $\mathrm{P}<0.05$

From the table data above it can be seen that there are significant differences in wound contraction between the control group and the other group. Meanwhile, between the standard group and the group given turmeric ointment at all times of observation found a significant difference in the magnitude of wound contraction. Meanwhile, the change in the concentration of Turmeric ointment to the large difference in wound contraction is insignificant at the beginning of the observation time, but the wound contraction difference between Turmeric ointment $5 \%$ and $10 \%$ begins to be observed on the last day of observation, namely on the 14 th day.

\subsection{Epithelial Period}

In addition to wound contraction, another parameter that is also evaluated in assessing burn healing is the epithelial period, the results of different tests from the epithelialization period of each treatment group can be seen in the table below.

Table 8. Results of Epithelial Period Comparison in Each Treatment Group

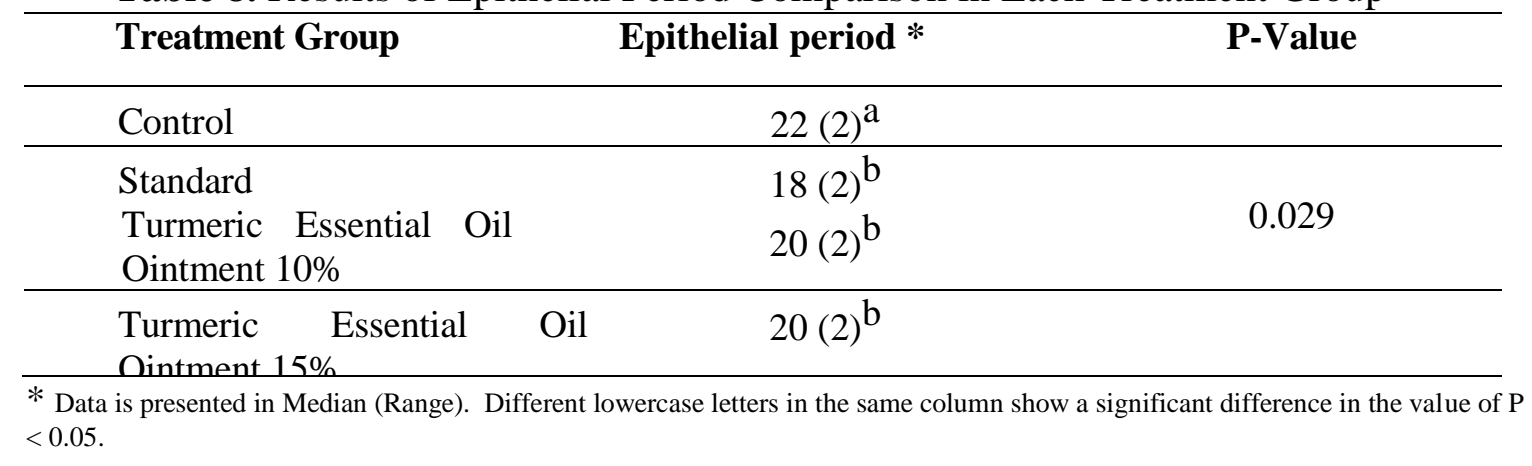

From the table data above it can be seen that there are significant differences in the epithelial period of the standard group, turmeric ointment $10 \%$ and $15 \%$ against the control group. However, in the turmeric ointment group and the standard group there was no difference in epithelialization periods. This is evident from the value $\mathrm{P}<0.05$ (Value $\mathrm{P}=$ 
0.029). Based on the results of the above study, it can be seen that there are significant differences in the wound contraction parameters and epithelialization periods of each treatment group.

Wound healing is a complex biological process that results in the recovery of integrity tissues. Physiologically, the wound healing process can be divided into four glutting values of hemostasis, inflammation, proliferation and tissue rermulelling. Many factors are known to slow wound healing, namely malnutrition, hypoxia. Immunosuppression, chronic diseases and post-surgical conditions. It is very important for the surgeon to understand the physiological processes involved in wound healing to maximize the patient's morbidity from the delayed wound healing process (Phillips 2000); (Young and McNaught 2011).

The results of this study are supported by the results of the study (Muthia Milasari 2019), who conducted research on the effect of yellow turmeric extract ointment on the healing of sores in white rats (Rattus norvegicus). The results showed significant differences in 5 groups $(\mathrm{P}<0.05)$. There are differences in the results of the study between the treatment groups (Ointment Extract. Yellow Turmeric 10\%, 20\% and 30\%) and positive control group ( $10 \%$ povidone ointment) and negative control (ointment base) showed the treatment group healed wounds faster than the control group. The conclusion is that the administration of yellow turmeric extract ointment $10 \%$ has the best effect in speeding up wound healing.

Also supported by the results of winarsih research, et al (2012), turmeric extract gel can reduce inflammation in the healing process of hyperglycemic back wounds (Winarsih, Wientarsih, dan Sutardi 2012). The enzyme content in Curcuma longa helps remove dead cells on the surface of the skin's epidermis damaged by wounds and amino acids can help regenerate cells very quickly. The content of vitamin A in turmeric can stimulate collagen formation so as to trigger recapitalization. Vitamin A and Vitamin E can also speed up the recapitalization process by increasing blood flow to damaged cells so that the process of restoring damaged epithelial cells is faster (Fitriani 2014). Vitamin C plays a role in cell differentiation, collagen synthesis, and increased proliferation of fibroblasts. In addition, vitamin $\mathrm{C}$ can also boost the immune system. This good immune state can improve the function of the immune system, so it can increase proliferation. Saponins are steroids or triterpenoid glycosides that play an important role in human and animal health. Saponins can trigger vascular endothelial growth factors (VEGF) and increase the number of macrophages migrating to the wound area thereby increasing the production of cytokines that will activate fibroblasts in wound tissue. Curcumin modulates the expression of TGF$\beta$ promotes collagen, fibrontin, and proteoglycan formation and stimulates the proliferation of fibroblasts (Akbik et al. 2014); (Budiman et al. 2015).

Tannins contain astringents to stop bleeding, speed up wound healing and reduce mucous membrane inflammation and regenerate new tissue. In addition, tannin content has antibacterial abilities. Tannin content accelerates wound healing with several cellular mechanisms, namely cleaning free radicals and reactive oxygen, increasing wound closure, and increasing the formation of capillary blood vessels and fibroblasts. Flavonoids in turmeric (Curcuma longa) serve as antioxidants, antimicrobials, and also antiinflammatory wounds. Flavonoids can help wound healing by increasing collagen formation, lowering tissue edema, and increasing the number of fibroblasts (Budiman et al. 2015). 


\section{Conclusion}

The results of phytochemical screening in Turmeric found phytochemical content in the form of flavonoids, alkaloids, and tannins. The healing effects of burns possessed by Turmeric ointment are both $10 \%$ and $15 \%$ and nebacetin ointment as standard show significant differences. Where the wound contraction rate of turmeric ointment is $15 \%$ better than nebacetin ointment as standard. But in both turmeric ointments both $10 \%$ and $15 \%$ and nebacetin ointment as standard did not show significant differences in the parameters of epithelial period.

\section{References}

Akbik, Dania, Maliheh Ghadiri, Wojciech Chrzanowski, and Ramin Rohanizadeh. 2014. "Curcumin as a Wound Healing Agent." Life Sciences 116(1):1-7.

Ariani, S. 2017. Stop Kanker, Cara Praktis Olah Tanaman Obat Kanker. Yogyakarta: Istana Media.

Avni, Tomer, Ariela Levcovich, Dean D. Ad-El, Leonard Leibovici, and Mical Paul. 2010. "Prophylactic Antibiotics for Burns Patients: Systematic Review and MetaAnalysis." BMJ (Online) 340(7745):517.

Badan Penelitian Dan Pengembangan Kesehatan Kementerian Kesehatan RI. 2013. Riset Kesehatan Dasar 2013.

Budiman, Iwan, Jalan Prof, Drg Suria, Sumantri Mph, and No Bandung. 2015. "RIMPANG KUNYIT ( Curcuma Longa Linn .) terhadap Luka Insisi pada Mencit Swiss-Webster Jantan Dewasa Turmeric ( Curcuma Longa Linn .) Wound Healing Activity Towards Incision on Wound Model of Adult Swiss-Webster Male Mice 1 Fakultas Kedokteran, Universita." Perpustakaan Maranatha Thesis.

Cobra, Lea Shella. 2019. "Skirining Fitokimia Ekstrak Sokhletasi Rimpang Kunyit (Curcuma Longa) Dengan Pelarut Etanol 96\%." Jurnal Ilmiah Kesehatan Karya Putra Bangsa 1(1):12-17.

Fitria, Meishinta, Deddy Saputra, and Gusti Revilla. 2014. "Pengaruh Papain Getah Pepaya Terhadap Pembentukan Jaringan Granulasi Pada Penyembuhan Luka Bakar Tikus Percobaan.” Jurnal Kesehatan Andalas 3(1):73-76.

Fitriani, Diah. 2014. "Pengaruh Ekstrak Kunyit Terhadap Peningkatan Jumlah Makrofag Pada Soket Pasca Pencabutan Gigi Cavia Cobaya." 1-4.

Hakim, Ashilah Mumtaz. 2020. "Efektifitas Aloe Vera Terhadap Luka Bakar." Jurnal Ilmiah Kedokteran Wijaya Kusuma 9(2):245.

Hartati, Sri Yuni. 2013. "Perkebunan_KhasiatKunyit.Pdf." Warta Penelitian Dan Pengembangan Tanaman Industri 19(2):5.

Itokawa, Hideji, Qian Shi, Toshiyuki Akiyama, Susan L. Morris-Natschke, and Kuo Hsiung Lee. 2008. "Recent Advances in the Investigation of Curcuminoids." Chinese Medicine 3:1-13.

Kalangi, Sonny J. R. 2014. "Histofisiologi Kulit.” Jurnal Biomedik (Jbm) 5(3):12-20.

Kocaadam, Betül, and Nevin Şanlier. 2017. "Curcumin, an Active Component of Turmeric (Curcuma Longa), and Its Effects on Health." Critical Reviews in Food Science and Nutrition 57(13):2889-95.

L.A. Usman. 2009. "Chemical Composition of Rhizome Oil of Curcuma Longa.Pdf." World Journal of Chemistry 4(2):171-81.

Lia Fikayuniar, Neni Sri Gunarti, and Mellya Apriliani. 2019. "Uji Aktivitas Antibakteri Ekstrak Etanol Rimpang Kunyit (Curcuma Longa L.) terhadap Staphylococcus 
Aureus dan Pseudomonas Aeruginosa." Pharma Xplore: Jurnal Ilmiah Farmasi 4(1):278-87.

Manarin, Gabriel, Daniela Anderson, Jorgete Maria e. Silva, Juliana da Silva Coppede, Persio Roxo-Junior, Ana Maria Soares Pereira, and Fabio Carmona. 2019. "Curcuma Longa L. Ameliorates Asthma Control in Children and Adolescents: A Randomized, Double-Blind, Controlled Trial.” Journal of Ethnopharmacology 238:111882.

Muthia Milasari, et al. 2019. "Pengaruh Pemberian Salep Ekstrak Kunyit Kuning (Curcuma Longa Linn) terhadap Penyembuhan Luka Sayat pada Tikus Putih (Rattus Norvegicus)." Jurnal Ilmiah Ibnu Sina 4(1):1-5.

Mutia, Levina. 2015. "Tirah Baring Di Ruang Rawat Inap Rsud Arifin Achmad Provinsi Riau Periode Januari 2011- Desember 2013.” Jom Fk 2(2):1-11.

Nabofa, Williams E. E., Oluwadamilola O. Alashe, Oyetunde T. Oyeyemi, Alfred F. Attah, Ademola A. Oyagbemi, Temidayo O. Omobowale, Adeolu A. Adedapo, and Akinola R. A. Alada. 2018. "Cardioprotective Effects of Curcumin-Nisin Based Poly Lactic Acid Nanoparticle on Myocardial Infarction in Guinea Pigs." Scientific Reports 8(1):1-11.

Nadifah, Fitri, Nurlaili Farida Muhajir, and Fitri Retnoningsih. 2018. "Daya Hambat Minyak Atsiri Rimpang Kunyit Terhadap Pertumbuhan Candida Albicans In Vitro." Jurnal Vokasi Kesehatan 4(1):1.

Negi, Jagmohan, R. Bisht, and S. Kandari Negi. 2012. "Major Constituents, Antioxidant and Antibacterial Activities of Zanthoxylum Armatum DC. Essential Oil." Iranian Journal of Pharmacology and Therapeutics 11(2):68-0.

Panghiyangani, Roselina. 2010. "Aktivitas Larvisida Minyak Atsiri Rimpang Kunyit Putih (Curcuma Zedoaria) Terhadap Larva Aedes Aegypti.” Majalah Kedokteran FK UKI 2010 XXVII(3).

Phillips, Steven J. 2000. "Physiology of Wound Healing and Surgical Wound Care." ASAIO Journal 46(6):2-5.

Razavi, et al. 2021. "A Review of Therapeutic Potentials of Turmeric (Curcuma Longa) and Its Active Constituent, Curcumin, on Inflammatory Disorders, Pain, and Their Related Patents." Phytotherapy Research (July):1-25.

Sabale, Prafulla, Arjun Modi, and Vidya Sabale. 2013. "Curcuma Longa Linn. A Phytochemical and Phytopharmacological Review." Research Journal of Pharmacognosy and Phytochemistry 5(2):59-68.

Safwan, Safwan, Sapto Yuliani, and Suwidjiyo Pramono. 2014. "Uji Aktivitas Minyak Atsiri Rimpang Kunyit (Curcuma Longa Linn) pada Tikus Sprague Dawley Model Demensia (Kajian Penghambat Aktivitas Asetilkolinesterase).” Kartika Jurnal Ilmiah Farmasi 2(2):20-26.

Setiadi, Adi, Nurul Khumaida, and Dan Sintho Wahyuning Ardie. 2017. "Keragaman Beberapa Aksesi Temu Hitam (Curcuma Aeruginosa Roxb.) Berdasarkan Karakter Morfologi." Jurnal Agronomi Indonesia (Indonesian Journal of Agronomy) 45(1):71-78.

Setyopuspito Pramitaningastuti, Anastasia. 2017. "Uji Efektivitas Antiinflamasi Ekstrak Etanol Daun Srikaya (Annona Squamosa. L) Terhadap Edema Kaki Tikus Putih Jantan Galur Wistar." Jurnal Ilmiah Farmasi 13(1):8-14.

Sirwutubun, Magdalena, Maya M. Ludong, Dekie Rawung, Jurusan Teknologi Pertanian, Fakultas Pertanian, Universitas Sam, and Ratulangi Manado. 2016. "Karakteristik Ekstrak Pewarna Alami Buah Merah ( Pandanus Conoideus Lamk .) Dan Aplikasinya Pada Produk Pangan.” Jurnal Teknologi Pertanian 7(5):1-8.

Thakur, Rupesh, Nitika Jain, Raghvendra Pathak, and Sardul Singh Sandhu. 2011. 
"Practices in Wound Healing Studies of Plants." Evidence-Based Complementary and Alternative Medicine 2011.

Tutik Rahayuningsih. 2012. "Penatalaksanaan Luka Bakar (Combustio)." Profesi 8:32.

Verma, Deepak Kumar, Masuram Bharat, Depaak Nayak, Tara Shanbhag, Venkatesh Shanbhag, and Ravindra Singh Rajput. 2012. "Areca Catechu : Effect of Topical Ethanolic Extract on Burn Wound Healing in Albino Rats." International Journal Pharmacology and Clinical Sciences 1(3):74-78.

Wanninger, Simon, Volker Lorenz, Abdus Subhan, and Frank T. Edelmann. 2015. "Metal Complexes of Curcumin - Synthetic Strategies, Structures and Medicinal Applications." Chemical Society Reviews 44(15):4986-5002.

Young, Alistair, and Clare Ellen McNaught. 2011. "The Physiology of Wound Healing." Surgery 29(10):475-79.

Zorofchian Moghadamtousi, Soheil, Habsah Abdul Kadir, Pouya Hassandarvish, Hassan Tajik, Sazaly Abubakar, and Keivan Zandi. 2014. "A Review on Antibacterial, Antiviral, and Antifungal Activity of Curcumin." BioMed Research International 2014. 